\title{
Lean Management Approach to Reduce Waste in HoReCa Food Services
}

\author{
Bartłomiej Gładysz ${ }^{1, * \mathbb{D}}$, Aleksander Buczacki ${ }^{1}$ (D) and Cecilia Haskins ${ }^{2}$ (D) \\ 1 Faculty of Production Engineering, Warsaw University of Technology, 02-524 Warszawa, Poland; \\ aleksander.buczacki@pw.edu.pl \\ 2 Department of Mechanical and Industrial Engineering, Faculty of Engineering, \\ Norwegian University of Science and Technology, 7491 Trondheim, Norway; cecilia.haskins@ntnu.no \\ * Correspondence: bartlomiej.gladysz@pw.edu.pl; Tel.: +48-22-234-81-26
}

Received: 5 October 2020; Accepted: 1 December 2020; Published: 8 December 2020

check for updates

\begin{abstract}
A significant share of food waste originates in the food services domain and HoReCa (hotels, restaurants, catering) sector. Organizational improvements leading to the decrease of food waste and costs in restaurants are needed. The literature reports on applications of lean management in service businesses, and while food services belong in this category, the literature contains few works on specific applications in this domain. Those studies are limited mainly to economic aspects. Nor was there evidence of the applicability of lean management to achieve food waste elimination. This article analyzes the applicability of lean management methods for food services in order to achieve efficient operations and eliminate food waste, based on a literature review and three case studies from Poland. Lean management was found to be useful in these cases to decrease food waste and reduce operational costs. The case studies suggest a set of activities for organizations delivering food services to streamline their processes by applying lean management practices. This study contributes to the theory and practice of sustainable restaurant management.
\end{abstract}

Keywords: food waste; lean management; food services; HoReCa; sustainable restaurant management

\section{Introduction}

The goal of this paper is to discuss lean management applications in the hotel, restaurant and catering businesses (frequently abbreviated HoReCa), and the possible contribution to the elimination of food waste with particular focus on waste generated in the food preparations area.

Specifically, this paper considers the following three categories of lean management tools: the identification and analysis of waste, the implementation of improvements and process monitoring [1]. A truly lean organization does not engage a one-time application of a particular tool or tools, but rather subscribes to continuous improvement as the whole organization strives to be efficient and effective.

Food waste prevention in food services gained the interest of researchers in developed countries (USA and Europe) in the 1910s, 1920s and 1940s [2-8]. Sadly, the interest was short lived and superseded by food supply problems for armies during World War I [3,4] and World War II [5,6]. Tracing the early scientific literature on food waste, apart from those few cited works on prevention and control, the main focus is on waste disposal [2,8]. The awareness of the importance of food waste prevention and reduction arose again in the early 1980s $[9,10]$.

Food is wasted along the entire food chain, starting from farms, plantations and fisheries, through processing, packaging facilities, logistics, transportation, distribution sites and warehouses, retail establishments, homes and restaurants [11,12]. A significant share of food waste is generated in the food services industry, including restaurants, bars, bistros, fast food chains, catering, etc. For example, a NRDC (Natural Resources Defense Council) report estimated that in 2015 in the USA 
alone $22-33$ billion pounds of food waste were generated by restaurants and a corresponding waste of 7-11 billion pounds from schools, hotels and hospitals [13]. It is reported that ca. 7\% of food is wasted in US restaurants before the consumer is served. Other countries' statistics are no better, e.g., food services are responsible for $12 \%$ of food waste in the European Union as determined for 2012 [14]. Sources of food waste include oversized portions [15], inflexibility of chain store management, extensive menu choices [13] and meals served mistakenly or delayed. Bloom [16] reported that in the USA, on average, $17 \%$ of meals are uneaten, while $55 \%$ of edible leftovers are left at the restaurant. According to research results conducted in selected European countries, on average, 20\% of meals are wasted in the hospitality sector [17]. Considering food waste in HoReCa, it is also very important to discuss consumers' habits, e.g., doggy bags [18] and normative actions to sensitize diners about the importance of the food waste issue [19].

Managing food waste is a global challenge that is recognized as an important issue in many economies. There are a number of works published in different contexts [20]. The food waste hierarchy proposed by Papargyropoulou et al. [21] suggests options for coping with food waste, i.e., (in order of attractiveness):

1. prevention, minimization of food surplus and avoidable food waste

2. distribution of food surplus to groups afflicted by food poverty

3. conversion of food waste to animal feed

\section{Background}

Lean management evolved from lean manufacturing, which is a well-established and widely implemented concept with a long history and abundant literature [22]. The lean approach is founded on delivering value through the elimination of seven types of waste, which were originally defined by Ohno [23] for the automotive manufacturing environment. Those types are transportation, inventory, motion, waiting, over-production, over-processing and defects. Those were later extended with an eighth type, which is unexploited skills. Interdependencies and influences, both positive and negative, between different types of waste should be considered during process analysis, for example, over-production in one part of the process can "create" inventory. Similarly, a reduction in the level of unnecessary motions in the process may reduce the probabilities of defects. Considering this typology of waste in an organization, over-production in food services emerges as a key driver of food waste [13,24]. Bicheno and Holweg [25] proposed a set of wastes tailored for service business. This set includes delays (customers waiting), duplication, unnecessary movement, unclear communication, incorrect inventory, lost (not retained or attracted) customers, errors in the service transaction (defects) and service quality errors. Organizations applying lean management observe the following principles [26]:

- Value-all activities of the company should focus on delivering value for the customers, external and internal, and needs of other stakeholders.

- Value stream-all activities should be considered as a unitary process, and changes in any part of the process should consider the potential influence of the change on the whole process.

- Flow-all processes should act without any backflows, delays or stoppages, and should operate in predictable manner.

- Pull—all processes should be activated only if there is demand of process product or even activity product (result). Under this principle no products are generated as stock.

- Perfection-all activities should be executed right the first time. Any repetitions or fixes violate this principle. If any problem does occur, immediate corrective action should be focused on the source of the problem for resolution.

Additionally, each lean organization focuses on human resource management, as employees are considered the most important asset of each organization, and without their acceptance and enthusiasm these principles would be ineffectual. The lean principles address activities that are required but do not 
add any value from the customer point of view (RNVA-Required Non-Value Added). These activities may be necessary because of administrative regulations or utilized technology. In practice, such activities are hard to eliminate or even hard to change. Other activities that are performed but do not generate any value for the customer are considered as pure waste (NVA-Non-Value Added), and such activities should be eliminated. Ideally, in a lean organization the processes should include only activities generating added value (VA).

Papargyropoulou et al. [27] used a case study of a Malaysian restaurant to illustrate the conceptual framework of food waste generation in the hospitality sector. They concluded that food provisioning, consumption and waste generation should be studied holistically to understand details of food waste sources (how, where and why) and to draw case specific food waste prevention plans addressing the material and socioeconomic aspects of food waste generation. An additional study found that the restaurant's operating procedures and policies and the social food consumption practices of consumers are the main causes of food waste in HoReCa [28]. This means that food waste reduction in these sectors should address both operational performance and the consumers' behavior and practices related to food preparation and consumption. Clowes et al. [29] studied 114 restaurants and found five actions to reduce food waste in restaurants, as follows:

- Measure. Generating a "food waste inventory" enabled sites to identify how much and where food was wasted, so managers could prioritize hotspots and monitor progress over time.

- Engage staff. Kitchen and service staff often want to help prevent food waste but need more definition and guidance from managers and owners.

- Reduce over-production. Certain production techniques contribute to a culture of over-production. For example, batch cooking, casserole trays, and buffets tend to overproduce food relative to cook-to-order preparation.

- Rethink inventory and purchasing practices. Restaurants that want to prevent food waste need to critically examine their current inventory management and purchasing practices.

- Repurpose excess food. Because forecasting customer demand is not a perfect science, restaurant kitchens will find themselves with extra ingredients and potentially wasted food. In these cases, planning alternatives to safely repurpose these ingredients can allow the kitchen to generate revenue from this potential waste, or alternatively contribute to a charitable cause.

Blum's [24] literature review on ways to reduce restaurant industry food waste costs identified three categories: processes to reduce food waste costs, strategies to reduce food waste costs and strategies to achieve food waste reduction. Reasons for food waste in restaurants include staff behavior such as over-preparation (over-production) of food, improper storage of ingredients and failure to use food scraps and trimmings [13], serving style and timing, type of food served and the prediction accuracy of the number of expected customers [30]. All-you-can-eat buffets were indicated as a particularly large problem, since extra food from a buffet cannot legally be reused or donated due to health code restrictions. While most owners and managers recognize the relevance of food waste to the profitability of their businesses, the incorporation of some of the main reduction strategies remains low [31]. Therefore, it is reasonable to take a closer look into lean management practices for dealing with waste in production organizations. From the operational point of view, food waste is generated at three points in the food service timeline as follows: pre-kitchen, in-kitchen and post-kitchen [31]. The case studies focus mainly on in-kitchen waste. However, in-kitchen waste can be influenced by pre-kitchen waste, i.e., excessive ingredients can lead to outdated food in the kitchen and wasted supplies.

Typical actions available in HoReCa to decrease food waste include:

- focus on forecasting demands [32] and adjusting supply practices through just-in-time practices and eliminating excessive inventory;

- appropriate serving and storing of fragile food including equipment and procedures (e.g., first expired first out rule) [33]; 
- processing edible leftovers [34] into other meals [35], animal feed [36,37], compost [38], biogas [39], as appropriate;

- $\quad$ sensitizing customers to the problem of plate leftovers and encouraging behavioral change $[18,19,40]$;

- forwarding edible leftovers to needy consumers [40], such as local charities, food banks, etc. [41].

\section{Methodology}

The research methods applied for this study are illustrated in Figure 1. First, a state-of-the-art review was performed for food waste generation and reduction in order to find current practices to define, detect, measure and mitigate food losses. Then, two scientific databases were selected for the literature review on lean management in restaurants, namely Web of Science and Scopus. The word gastronomy was used to capture the widest possible sources. One query was used for the search within titles, keywords and abstracts with no time restrictions (1):

lean management AND (HoReCa OR restaurant OR gastronomy OR catering)

Exact Scopus query was:

TITLE-ABS-KEY (lean AND management) AND TITLE-ABS-KEY (HoReCa OR restaurant OR gastronomy OR catering)

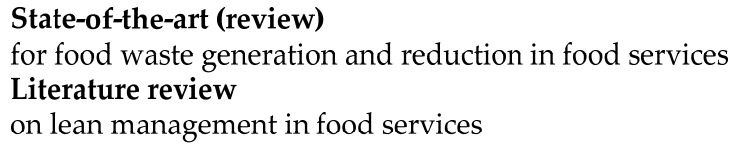

\section{Case study}

(multiple, explanatory, instrumental, organization-

based) on lean management applications in restaurants
Develop a framework for lean management

toolset for reducing food waste in food services

Matching lean tools with actions to eliminate food

waste and sources of food waste

Figure 1. Research design.

In total, 25 sources were found. We excluded all non-English papers. Sources in English were selected for each query including all types of works (books, articles, proceedings). Abstracts were screened, to choose sources of interest for further investigation that relate to lean management and not to domains where lean means fit/healthy/balanced about food and its dietary characteristics. We excluded all papers that were not focused on application of lean management programs, but the term "lean" was used as an adjective to describe food from dietary viewpoint (lean food, lean diet, etc.). There was no date criterion used for exclusion/inclusion. Finally, 10 sources were selected from Scopus [42-51]. Additionally, Google Scholar sources were investigated for the same query (Equation (1)). First 30 results, sorted by Google Scholar due to relevance, were screened using the same inclusion/exclusion criteria. An additional 4 sources were selected [52-55]. A summary of each paper is presented in Table 1.

Case studies from WUT postgraduate dissertations were selected to extract and discuss phenomena of lean management and its possible application in HoReCa. An exploratory approach was used as the goal was two-fold [56]. First, to investigate if lean management in the food services sector is worthy of additional research. Second, to derive an understanding about applying lean management techniques in HoReCa based on the cases. A framework for a lean management toolset for reducing food waste in food services was developed by searching for similarities of tools and results achieved within analyzed case studies. 


\section{Results}

This section reports on an analysis of the literature review and the multiple case studies. Insights gained are then mapped onto lean tools and practices to generate guidelines for the application and implementation of lean management for the HoReCa business sector.

\subsection{Lean Management Applications in Food Services}

Although the literature on lean applications in the services sector is very rich, only seven papers were directly related to lean management in the food services domain based on the criteria established above. The majority of publications concentrate on cases of food manufacturers [57] or whole food sectors [58]. Table 1 presents a summary of reviewed literature, including sources related to food waste and additional articles cited by the primary sources. Based on this table the most interesting and useful sources are discussed further.

Table 1. Lean management applications in food services.

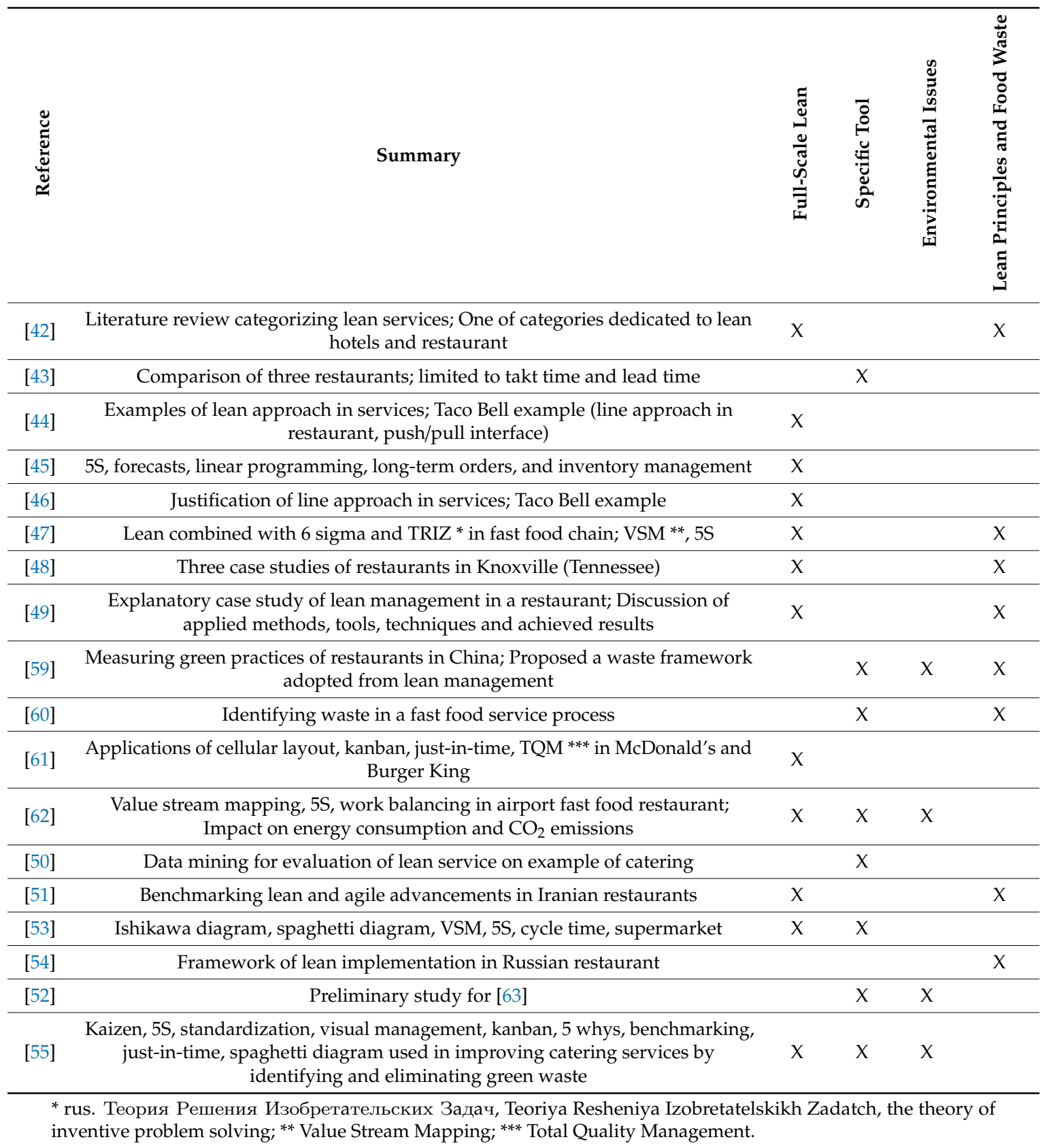


Lean restaurants, together with hotels, are treated as one of the categories of lean food services. The articles found in the literature in this category are case-stories, anecdotes and general practitioner-oriented narrations on successful applications, but pitfalls, barriers and shortcomings are marginalized or even omitted [42]. The gap between theory and practice indicates a clear need for a more thorough definition of what lean management actually means in the HoReCa sector. Various organizations apply some principles of lean, but label it differently, making it difficult to attribute any successful practices to a specific lean management principle.

Some articles adopted a comprehensive review of lean management approaches and reported details of applications of full-scale lean programs [42,44-49,51,53,55,61,62]. Others addressed one or more specific tools $[43,50,52,55,59,60]$, environmental issues $[52,55,59,62]$ or proposed lean implementation and waste frameworks for HoReCa $[54,59,60]$.

The "production line" approach, one-piece flow and continuous flow principles in fast food restaurants were reported to be effective approaches in various studies $[44,46,61]$. Value chain analysis led to the separation of flows for common semi-products (like meats, cheese, sauces and others) and final assembly, where common semi-products are located in specialized units outside the restaurant and only final assembly is performed in these restaurants. This approach is an application of maintaining in-house control over the highest value-added components of their business processes and off-loading other activities to vendors or specialized facilities. Supplies of semi-finished products are organized in a just-in-time manner and assembly in restaurants is pulled by the customer as illustrated in the top portion of Figure $2[44,46]$. Not only fast-food chains, but also high-end restaurants, effectively applied solutions based on Kanban, just-in-time, cellular layout, continuous flow and total quality management (TQM) [61]. Information about customer orders and the volume of delivery orders flow in the opposite direction from the products. The flow of such information can be done through Kanban cards.

PHYSICAL FLOW
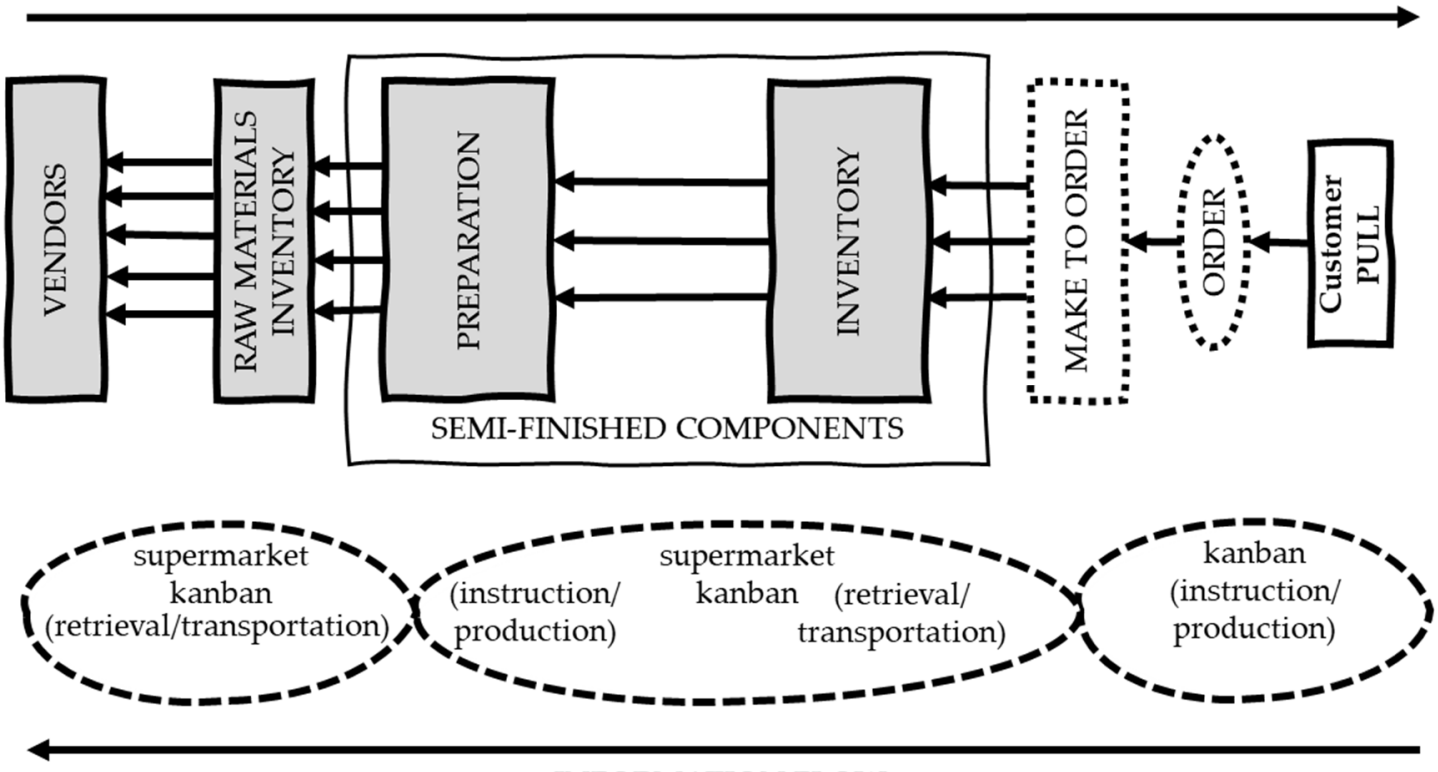

INFORMATION FLOW

Figure 2. "Lean" restaurant adapted from [61]

The other subset of works [45,47,48,53] addressed applications of most basic lean tools, e.g., 5S, and visual management, accompanied by other basic tools, such as menu engineering (forecasts, linear programming, long-term orders and inventory management) [45], spaghetti diagrams [53], kaizen workshops and just-in-time [48], or supplemented with other approaches, such as TRIZ and 6 sigma [47]. Visual management supported two goals: improving product flows in a kitchen and improving inventory management. Benefits reported included savings of utilized space and 
elimination of worker movements (decrease of number of operations performed within an area of $1 \mathrm{~m}$ from workstation), lower stock and shorter stock rotation.

Other papers contained limited discussions or links with lean management that were rather fuzzy or mentioned only one specific tool, e.g., takt time calculations for benchmarking [43], an auditing tool for food waste in restaurants [60] and a data mining approach to the analysis of a catering lean service project [50]. Once again the importance and applicability of line approach and flow improvements was demonstrated, but on a limited scale [43].

LeGrand et al. [49] presented the only thorough description of a case of lean application in a restaurant. They applied the DMAIC (Define Measure Analyze Improve Control) framework to the project, as known from Six Sigma methodology. For each of the DMAIC stages, a description and tools (with exemplary illustrations) are presented including goal definition, value stream mapping, voice of customer, Pareto analysis, cause and effect diagram, 5S, pull system (Kanban), standardization, spaghetti diagrams, control charts, cost/benefit analysis and Hoshin Kanri (policy management). This study serves as a very detailed illustration of good practices for practitioners. Rahimnia et al. [51] presented a combined application of lean and agile paradigms in an Iranian fast food chain by studying the decoupling point in the supply chain, i.e., identifying push/pull interface position in the chain and decreasing variety in products and demands (Heijunka).

Another category of papers on lean approaches applied in HoReCa relates to environmental issues, not including food waste. There is no single consistent topical stream in this category. Different authors reported a framework for measuring, monitoring, managing green practices and classifying waste in restaurants [59], contribution of lean tools (VSM, kaizen, and 5S) to increase work efficiency, decrease of cycle times and reducing energy consumption and $\mathrm{CO}_{2}$ emissions while maintaining a high level of quality in restaurants [62].

Considering reasons for food waste and actions available to reduce it [13,29], lean management principles and goals are in line with actions necessary to eliminate sources of food waste in HoReCa. However, there is limited empirical evidence reported of this relationship. Therefore, the goal of this study is to discover if such evidence exists and develop a framework to support lean management implementation oriented toward food waste elimination.

\subsection{Multiple Case Study}

All cases discussed in this study are businesses operating in Poland, were prepared by practitioners conducting action research and employed on a full-time basis or as consultants. The variety of food services included a cafeteria, a catering company and an inn, covering each of the HoReCa domains. All cases were initiatives led by the respective organizations and offered to the university (WUT) for postgraduate studies on lean management. Each project was supervised by both academics and consultants who conducted the postgraduate course and supervised the written report or thesis.

\subsubsection{Cafeteria and Board Games Club}

The first case study is a small cafeteria in a university town providing two services, namely board games and food [63]. The services are oriented towards board game fans with food/beverages available at the table. Peaks are observed on weekends and the customers also exhibit annual patterns. The seasonal and weekly variances may result in waste (jap. muda) of inventory or a shortage of inventories, workers' overload (on weekends) and underload (on weekdays), with similar patterns caused by the seasonal nature of customers who are mostly students. Margins on food supplies were typically low, and the business was also challenged by organizational issues (food preparation, communication). Interviews with employees and an organization audit were conducted by the researcher. Interviews showed different perceptions and miscommunication between staff and management. It was noticed that workplaces for preparing food were ad hoc rather than fixed and organized. The only stations that could be defined were those related to specific processes, equipment or 
machines, such as the sink or stove. Visual management was limited to handwritten labels on boxes with herbs. Few and outdated work instructions were available.

When the project began, the lead times for the preparation of basic meals, like a sandwich, varied from 10 to $25 \mathrm{~min}$, and there were no standards (written recipes). The researcher observed that this led to wasted motion (e.g., moving to another room to collect ingredients), waiting (e.g., until other workers peeled vegetables, warmed milk, etc.) and defects (e.g., incorrect sides added to a plate before serving). These three factors contributed to food waste in the preparation of meals.

Three representative products (toast, hot chocolate, a plate of cold cuts) were chosen for detailed analysis. The researcher selected two analysis tools to help document and then improve the wasted motion and lack of recipes: a spaghetti diagram and job breakdown. A spaghetti diagram is defined as a visual representation using a continuous flow line tracing the path of an item or activity through a process. As a process analysis tool, the continuous flow line enables identification of redundancies in the workflow and opportunities to expedite a process. Spaghetti diagrams are useful for creating lean practices for training-within-industry (TWI) [64]. Spaghetti diagrams (Figure A1 in Appendix A) and job breakdown through job instructions (Table A1) were prepared from measurements collected during random observations. Random observations clearly indicated the low productivity of employees, which could easily be attributed to lack of training, high variability of products, lack of standards and instructions, poor and ad hoc workplace organization and ergonomics, and the poor layout of the kitchen itself not reflecting process sequences.

Given the analysis of the then current state, the goal of the proposed lean program was directly related to process efficiency and food waste reduction with a focus on:

- Layout redesign using a product-oriented line approach and flow principles for food preparation, which resulted in shortened lead times and food served in a timely manner (warm), which translated into reduced food waste.

- Implementation of visual management and standardization to strengthen layout redesign; clear marking of inventory and replenishment labels) enabled execution of a first-expired first-out priority rule and maintaining stock levels adequate to demand, which resulted in a decrease of food waste due to expiration dates and spoilage.

- Establishing a training and career program for employees that considered both implementation of lean management tools and their impact on food waste reduction. These programs were addressed for all restaurant personnel, including management, kitchen staff and waiters.

Shortly after these initiatives were implemented the total cost of a meal decreased by $15 \%$ (see Table A2 for itemization). The lean program was initially divided into six general stages as summarized in Table 2.

Table 2. Implementation of the lean program in a Polish cafeteria.

\begin{tabular}{|c|c|}
\hline Step & Techniques \\
\hline Identification of waste & $\begin{array}{l}\text { Interviews (structured, with list of searched data) with all employees; Gemba walk; } \\
\text { Random observation; TWI (Training Within Industry); Job instructions; Spaghetti diagram }\end{array}$ \\
\hline Program launch & Mentoring; Training; Literature/readings distribution \\
\hline Strategic goals setting & $\begin{array}{c}\text { SWOT (Strengths, Weaknesses, Opportunities, Threats) analysis; Brainstorming; } \\
\text { ERRC (Eliminate-Reduce-Raise-Create) diagram }\end{array}$ \\
\hline Program management & $\begin{array}{l}\text { Brainstorming; Prioritization; Planning poker; KPIs (Key Performance Indicators); } \\
\text { Kanban for project management }\end{array}$ \\
\hline Elimination of waste & $\begin{array}{l}\text { 5S; New layout design, Kanban; TWI job instructions; Standardization; } \\
\text { Visual management; Motivational system; Matrix of competences; Suggestion system }\end{array}$ \\
\hline Continuous improvement & $\begin{array}{c}\text { Interviews with all stakeholders; Strategic planning; Brainstorming; Suggestion system; } \\
\text { Gemba walk }\end{array}$ \\
\hline
\end{tabular}


Formal communication and control of the lean program were enabled by a Kanban board for project management [65] and weekly operational meetings. Six statuses for tasks were defined as follows: 1/backlog, 2/to do, 3/in progress, 4/to be accepted, 5/implementation (optional step after acceptation), 6/finished.

Responsibilities of management, consultants and workers were defined and communicated among the whole team. SWOT/TOWS analysis and an ERRC diagram (also known as the Blue Ocean Leadership Grid) [66] were prepared using planning poker [67] for assessment of weights and priorities. Elimination of waste was addressed using the $5 S$ practices. The scope of $5 S$ in the beginning included all rooms where food is prepared. Layout redesign and workplace organization played important roles in elimination of waste. Small improvements (for example disassembling doors of cupboards) as well as significant changes were implemented (for example, redesign of layout and workstations design regarding the flow of food preparation process-Figure A2). The new layout design led to reduced preparation times which in turn meant a higher number of meals served on time and warm, and a decrease of food waste. Throughout the process, $5 \mathrm{~S}$ implementation achieved the following results:

1. Sort (jap. seiri): recovery of ca. $30 \%$ of space, which was reallocated for additional kitchen tasks; achieved by removing four unnecessary pieces of furniture and ca. 40 utensils, transforming unused cupboard into additional working table, installation of 3 additional running meters of the working table

2. Set in order (jap. seiton): allocation of necessary utensils to workstations, visual marking of utensils, hanging utensils in front of a workstation meant more space on the working tables

3. Shine (jap. seiso): establish daily schedules for cleaning the working areas and storage furniture, and allocate a separate area for cleaning equipment

4. Standardize (jap. seiketsu): introduction of a standardized internal audit form and the procedure for analyzing it; training staff on the procedures

5. Sustain/self-discipline (jap. shitsuke): institute safety and health training, cleaning training

5S implementation included design of a separate area to store cleaning equipment, cleaning schedule, audit form and plans for continuous improvement. All improvements were supported with visual management. In order to achieve stability of processes, new working instructions, aligned with the new layouts, were introduced. It is worth mentioning that the level of details included within each instruction increased significantly (see Table A3). This allowed better training of workers and fewer errors.

One of the other viable issues that emerged from interviews and random observations was lack of employee motivation and poor training. Expectancy theory was adopted to gather employees' expectations and evaluate the impact of different rewards on the level of motivation [68]. Employees were surveyed using a questionnaire. Answers received indicated dissatisfaction for questions related to personal development, learning and career promotion potential and results, which motivated the development of career path progressions. The empowerment approach was also adopted. Decisions became faster through the development of a competence matrix and clear definition of responsibilities and authorities for each employee. Additionally, managers saved time through delegation of some responsibilities to staff.

All proposed improvement led to a decrease of everyday setups (before opening hours) by circa $50 \%$. Since inventory was also found to be a source of waste (see Table A2), a pull system was introduced. Refresh levels were estimated for each material stored in a kitchen, and they were visually marked. Continuous review of inventory control meant that if warehouse inventory reached a predefined minimum, then a worker adds that material to a supply order list. Kitchen inventories were decreased by $40-65 \%$. This helped significantly reduce the spoilage of fresh ingredients with limited shelf-life. 


\subsubsection{Railway Food Services Facility}

The second case study was the central food services facility for a Polish passenger railway company [69]. This is a large company with two core businesses: catering and food preparation for the restaurants located in dining cars. For each core business, the company utilizes dedicated equipment, in particular equipment for raw materials preparation, quick cooling and refrigerated storage. However, since some equipment is involved in both core businesses, it is not possible to completely separate the operation processes. Production approaches vary for each business. For the catering business, ready-to-serve meals are produced and delivered in appropriate containers and packages to be served at the customer location. The ready-to-serve meals are products that could follow mass production principles. In the case of products for railroad restaurants, semi-finished products with a limited range are prepared according to a process consisting of the following stages:

- Preparation of raw materials (washing, peeling, cutting)

- Composition of the dish by compilation of selected raw materials

- Vacuum packing

- Cooking combined with pasteurization

- Quick cooling

- Refrigerated storage

The project was started with the following goals: identify defects per stage and fix these defects utilizing selected kaizen and lean tools. For creating lean programs, 3M (muda, mura, muri) analysis is typical, including in the first case study. At the analysis stage all classic wastes (over-production, waiting, unnecessary movement, over-processing, inventory, defects) were identified and evaluated using the basic analysis tools, e.g., spaghetti diagrams for motion related to the various types of meals. Based on spaghetti diagrams some layout changes as well as technology process adjustments were proposed, which shortened motions for the most critical products. Additional actions were taken to comply with Hazard Analysis and Critical Control Points (HACCP) requirements:

- The technological lines were redesigned so that the flow of raw materials, semi-finished and finished products takes place in one direction. The process redesign also considered internal storages (cold rooms) reallocation as well as creation of smaller cold rooms co-located in the various places of "production processes".

- The production processes were developed so that their execution could take place in the shortest possible time. This combined with the previous bullet enabled lead times to decrease, an increase in the timely service of meals (warm), and efficient flow of smaller batches, which resulted in reduced inventory levels of ingredients and led to decrease of food waste.

- Crossing "clean" with "dirty" routes was eliminated; this eliminated cases of spoiling clean food and, therefore, decreased food waste.

As with the first case study, the new layout design improved process flow and eliminated unnecessary transportation through the introduction of product-oriented working cells. Additionally, tools, utensils, packaging and workwear were collated by color to indicate the type of food being processed. This case also achieved reduction of food waste thanks to better and more transparent inventory management, including quicker rotation for ingredients (decreased levels of inventory). The main expectations of the railway customer implementing these changes was more effective utilization of facilities, and this was met with increased productivity of processes up to $12 \%$. Redesigned processes were expected to be more flexible to accommodate the constantly changing demand and serve as a basis for further improvements, both in technology and operational activities. The lean improvement program was coupled with a large investment program and the cooperation of top management. 


\subsubsection{Small Inn}

The third case study [70] was aimed at improving efficiency of the food services in a small Polish inn with only 12 employees. The problem definition was based on the strategy analysis (SWOT), which identified the following service lines:

- Preparing and serving food to travelers

- Organizing special events such as weddings, birthdays, baptisms

The company looked for ways to increase productivity and assure process stability with uncertain and changing demand. The project started with the waste analysis considering the aforementioned classic types of waste. Inventory management and defects were defined as the most critical issues for the company. Results from muda analysis suggested the following improvement program:

- Appointment of the lean change team; the team leader (kaizen coordinator) became co-owner of the company

- $5 S$ implementation both in kitchen and dining room

- Establishment of the metric system for the operational activities of the company

- Improvement of order fulfillment process flow, in particular accounting for inventory management based on visual management and Kanban implementation

- Personnel involvement throughout using mini-kaizen sessions focused on problem identification with immediate implementation of small improvements and defining and implementing a suggestion system; during mini-kaizen sessions, personnel learned the 5 whys and other problem identification tools, methods and techniques.

The recommendations for the lean program implementation relied on support from the organizational culture in the company and will be the basis for further operational improvements. The lean tools implementation confirmed that basic tools (5S, visual management) are easily applicable in HoReCa organizations and can support the HACCP management systems implemented in the inn. Throughout lean implementation, an observable reduction of inventory of ingredients as well as intermediates was achieved, thereby influencing both the reduction of food waste and increased company profitability.

\subsubsection{Summary of the Polish Case Studies}

The summary of the cases is presented in Table 3. Commonalities within the case studies are italicized. This includes tools used for identification and analysis, improvement and process monitoring purposes. In addition, the scope of the lean implementation for each case as well as achieved or expected results are included.

It should be noted that tools implemented in all cases are basic ones applied in early stages of lean management programs, namely:

- Spaghetti diagrams and gemba walk-for identification of waste

- $\quad 5 S$ and standardization-for improvement implementation

- Visual management-for process monitoring and physical layout

In addition, strategic analysis using SWOT/TOWS is the beginning point in each of the three case studies. Interestingly, all improvements were focused mainly on layout redesign, which shows that improving flow is still the primary issue for food preparation. Layout redesign was logically related to process redesign as it usually is for lean applications. There is also evidence in the literature confirming this observation $[44,46,49,61]$. The case studies also confirmed that production control techniques (Kanban) are applicable for food services and human factors in the form of motivation, suggestion systems and staff involvement are critically important.

All three cases are written from the vantage point of companies beginning their lean implementation path. The primary goal of lean implementation is the continuous improvement of operational capability. 
However, in the first two cases some substantial effects were achieved quickly. Lean implementation afforded a possibility of strengthening the competitive position for all three cases.

Table 3. Summary of case studies.

\begin{tabular}{|c|c|c|c|}
\hline & Case 1 & Case 2 & Case 3 \\
\hline $\begin{array}{c}\text { Tools used for } \\
\text { identification and } \\
\text { analysis of waste }\end{array}$ & $\begin{array}{l}\text { Spaghetti diagram } \\
\text { Gemba walk } \\
\text { SWOT/TOWS } \\
\text { Brainstorming }\end{array}$ & $\begin{array}{c}\text { Spaghetti diagram } \\
\text { Gemba walk } \\
\text { SWOT }\end{array}$ & $\begin{array}{c}\text { 5Why } \\
\text { Gemba walk } \\
\text { SWOT } \\
\text { Mini-kaizen }\end{array}$ \\
\hline $\begin{array}{l}\text { Tools used for } \\
\text { improvements } \\
\text { implementation }\end{array}$ & $\begin{array}{c}5 S \\
\text { Standardization } \\
\text { Process balancing }\end{array}$ & $\begin{array}{l}5 S \\
\text { Standardization } \\
\text { Daily meetings }\end{array}$ & $\begin{array}{c}5 S \\
\text { Standardization }\end{array}$ \\
\hline $\begin{array}{l}\text { Tools used for } \\
\text { process monitoring }\end{array}$ & $\begin{array}{l}\text { Visual management } \\
\text { Kanban }\end{array}$ & Visual management & $\begin{array}{l}\text { Visual management } \\
\text { Kanban }\end{array}$ \\
\hline $\begin{array}{c}\text { Scope of } \\
\text { implementation }\end{array}$ & $\begin{array}{l}\text { Layout redesign } \\
\text { Process redesign } \\
\text { Suggestion system } \\
\text { Motivation system } \\
\text { Matrix of competencies }\end{array}$ & $\begin{array}{l}\text { Layout redesign } \\
\text { Process redesign } \\
\text { Designation of area } \\
\text { leaders }\end{array}$ & $\begin{array}{l}\text { Layout redesign } \\
\text { Suggestion system } \\
\text { Staff involvement }\end{array}$ \\
\hline $\begin{array}{l}\text { Expected/ achieved } \\
\text { operational results }\end{array}$ & $\begin{array}{c}\text { (Achieved) Lead time } \\
\text { reduction ca. } 60 \% \\
\text { Number of operations } \\
\text { reduction ca. } 53 \% \\
\text { Cost of labor reduction ca. } 62 \% \\
\text { Inventory reduction ca. } 65 \% \\
\text { Space reallocation }\end{array}$ & $\begin{array}{l}\text { (Expected) Process } \\
\text { path reduction } \\
\text { (Achieved 12\% } \\
\text { process efficiency) } \\
\text { Space reduction }\end{array}$ & $\begin{array}{l}\text { (Expected) Inventory } \\
\text { reduction } \\
\text { Lead time reduction }\end{array}$ \\
\hline
\end{tabular}

\subsection{Lean Management Framework for Reducing Food Waste in Food Services}

Considering five actions to reduce food waste in restaurants as proposed by Clowes et al. [29], it is possible to develop a framework of recommended lean management tools to support food waste reduction in food services (Table 4). The framework is intended for managers who could identify actions not previously considered and could draw a roadmap for further actions in their lean initiatives and quest for continuous improvement. This exercise illustrates that not all lean methods are equally effective in food waste reduction. During the implementation, owners and managers should choose appropriate methods, be aware of the effort related to the particular tool implementation, monitor the expected (achieved) effect and support the advancement of the organization in practicing lean management.

Table 4. Lean management framework for food waste reduction in food services.

\begin{tabular}{ccc}
\hline $\begin{array}{c}\text { Action as Defined } \\
\text { by [20] }\end{array}$ & $\begin{array}{c}\text { Lean Management } \\
\text { Tools/Techniques/Methods }\end{array}$ & Contributing Factors/Indicators \\
\hline Measure & Visual Management & ingredients stock, outdated food, serving lead time \\
\hline Engage staff & $\begin{array}{c}5 \mathrm{~S} \\
\text { Kaizen }\end{array}$ & $\begin{array}{c}\text { incorrect or delayed meals, personnel engagement, } \\
\text { staff meals, career progression }\end{array}$ \\
\hline $\begin{array}{c}\text { Reduce over- } \\
\text { production }\end{array}$ & $\begin{array}{c}\text { Forecasting, leveling, Heijunka } \\
\text { Kanban (production) } \\
\text { Portfolio management } \\
\text { (short menu) } \\
\text { TWI }\end{array}$ & $\begin{array}{c}\text { Thize of meals, ingredients stock, cooking batches, } \\
\text { edible leftovers, nonedible leftovers, plate leftovers, } \\
\text { serving lead time }\end{array}$ \\
& Visual management & \\
\hline
\end{tabular}


Table 4. Cont.

\begin{tabular}{|c|c|c|}
\hline $\begin{array}{l}\text { Action as Defined } \\
\text { by [20] }\end{array}$ & $\begin{array}{c}\text { Lean Management } \\
\text { Tools/Techniques/Methods }\end{array}$ & Contributing Factors/Indicators \\
\hline $\begin{array}{l}\text { Rethink inventory } \\
\text { and purchasing } \\
\text { practices }\end{array}$ & $\begin{array}{l}\text { Just-in-time (JIT) } \\
\text { Kanban (inventory) } \\
\text { Standardization } \\
\text { Portfolio management } \\
\text { (short menu) } \\
\text { Visual management }\end{array}$ & $\begin{array}{c}\text { level of stocks, number of ingredients, amount of } \\
\text { outdated food, sales, } \\
\text { serving lead time, } \\
\text { donations to charity, } \\
\text { leftovers taken/not taken by consumer, } \\
\text { size of meals }\end{array}$ \\
\hline $\begin{array}{l}\text { Repurpose excess } \\
\text { food }\end{array}$ & $\begin{array}{c}\text { Kaizen } \\
\text { Menu planning }\end{array}$ & $\begin{array}{c}\text { edible leftovers, reprocessed leftovers, number of } \\
\text { ingredients, number of meals, } \\
\text { plate leftovers }\end{array}$ \\
\hline
\end{tabular}

\section{Discussion}

After the initial analysis and problem investigation, implementation of $5 \mathrm{~S}$ and layout design were the most frequently taken initial steps of implementation of a lean program for food services as reported in both the literature and the Polish case studies. Two of the analyzed organizations (Case 1 and 3) were small, and processes were not too complex, so detailed value stream mapping was not necessary for waste identification, and consequently the lean program focused on motion wastes (Space) and improvement of food preparation (e.g., number of ingredients). However, the potential for additional improvements is clearly suggested by Table 4 , and there should be more detailed business analysis of value streams. Product and flow orientation are crucial in lean management. It is not possible for every food preparation facility to arrange workstations in a line layout, as it was in the case of Taco Bell [44], McDonald's and Burger King [61]. Nor is it necessary given the wider portfolio and higher variability of orders found in a fast food restaurant. Therefore, hybrid layouts were implemented for the in-kitchen solution for the cafeteria, including product-oriented cells (see working tables in Figure A2). Lead time reductions (elimination of transport operations, reduction of transportation routes) are typical for lean programs, as reflected by placing working tables close to cooperating areas (stoves, sinks, coolers, small appliances). The other topic that was considered was the elimination of inventory waste. Pre-kitchen inventory control in food preparation rooms was improved through implementation of pull signals, which were achieved in these cases by simple visual management of inventory levels. Continuous review of inventory control is recommended as it is one of the main elements that has a measurable impact on food waste reduction by reducing the losses from outdated food. These techniques are neither specific, tailored for HoReCa, nor sophisticated. Neither are the reported approaches used for project management particularly specific or sophisticated.

The implementation of lean management in Case 1 confirmed its applicability and the corresponding usability of lean management (lean services) approaches for the small cafeteria. Decrease of lead times by ca. 55\% (preparation of meal) led to tangible and significant monetary effects, i.e., $16 \%$ decrease of total costs. Seven levels of worker empowerment and a TWI program were established, resulting in worker's ability to work independently (alone) in the kitchen rooms during the preparation of meals without supervision (after successful training), and with a lower level of routine control by the owner. This freed ca. $1.5 \mathrm{~h}$ per day of the owner's time that could be spent on non-operational business activities.

All presented solutions are rather similar. However, the use of spaghetti diagrams and the elements of a TWI program in restaurants are the factors that distinguish these approaches from other cases discussed in the literature review. It is hard to find specific characteristics of the presented lean program that distinguish lean management in food services from any other lean services program. Nevertheless, the lean approach was confirmed to have big potential for savings in HoReCa services when based on tools such as 5S, spaghetti diagrams, just-in-time, TWI, standardization, continuous flow, flow-oriented layout and visual management. While only a limited set of simple lean techniques were 
applied, the results achieved in the presented case studies were achieved in a relatively short time and are very promising for further research in the HoReCa domain. However, it is not possible to assert that a lean management approach has superior advantages over other approaches or if any rational improvement approach would deliver comparable savings.

Some advanced lean methods were not implemented in the Polish case studies. For example, JIT may support improvement of some restaurant operational indicators, i.e., shortening serving lead time, decreasing cooking batches, and as a consequence decreasing ingredients stock. These indicators affect changes of indicators related with food waste, such as the value of outdated food, and edible or nonedible leftovers. However, it should be stressed that JIT implementation needs more effort from the implementation team and initially expected results will not be seen as significant. Implementation of advanced methods require more advanced tools for process flow analysis-VSM (Value Stream Mapping) or computer flow simulation. Forecasting and portfolio management implementation supports control of cooking batches, ingredients stock, serving lead time and affects indicators related with food waste, size of meals and leftovers taken by consumer. The lean approach could be also implemented in other areas of the restaurants' activities (not only focused on operation), i.e., recipes of meals development. Lean management of meals development could influence the number of ingredients, the number of meals (in menu, i.e., menu size), the size of meals and the amount of leftovers taken by consumers.

One significant source of food waste is the insistence on the part of owners to provide a high level of service through constant availability of the whole assortment of fresh meals. For this reason, it is important to focus efforts in the following five directions, some of which are outside the influence of food service lean management:

- $\quad$ accurate demand forecasting

- designing food preparation processes resistant to fluctuations in demand

- designing recipes of dishes with ingredients that have longer shelf life

- change in the perception of the standard of high service by customers

- the introduction of appropriate legal and tax regulations encouraging restaurateurs not to generate food waste

\section{Conclusions}

Lean management tools mainly support the operating activities, which in turn may contribute to food waste reduction. Further steps for this research are underway. Systems dynamics modeling will be applied to simulate the relationships and corresponding impacts of different lean tools on different indicators affecting final food waste in food service organization. After reviewing the case studies and observing the similarities between the approaches to reducing food waste through the application of lean principles, the authors considered the value of capturing the dynamics surrounding food waste in the food service sector in a causal loop diagram (CLD). The proposed system dynamics model will integrate relationships between different, critical business factors, i.e., sales and critical environment factors related to food waste. However, further research is needed to gather data that supports a realistic simulation using system dynamics modeling. The diagram will present a reference framework that could be of interest to food service businesses considering ways that food waste reduction creates a positive overall impact on sales and, eventually, profitability of their enterprise. Combining the knowledge of interrelated factors with the lean management practices can help a food service business to set reasonable goals and identify useful practices, such as physical layouts, more flexible processes in case of fluctuating demand and simplified menus to improve their operations. The CLD could be used to define a roadmap for helpful lean initiatives. Applying the framework, practitioners could see clear relationships, analyze feedback loops, plan and coordinate their actions accordingly. 
Author Contributions: Conceptualization, B.G. and A.B.; methodology, B.G., A.B. and C.H.; software, B.G. and A.B.; validation, C.H.; formal analysis, B.G., A.B. and C.H.; investigation, B.G. and A.B.; resources, B.G. and A.B.; data curation, B.G. and A.B.; writing-original draft preparation, B.G. and A.B.; writing-citations, review and editing, C.H.; visualization, B.G.; supervision, B.G. and A.B.; project administration, B.G.; funding acquisition, A.B. All authors have read and agreed to the published version of the manuscript.

Funding: The APC was covered from internal Warsaw University of Technology grant for management and quality sciences (A.B.).

Acknowledgments: Authors would like to thank students of postgraduate course Kaizen Academy, whose final dissertations constituted a basis for multiple case study presented in this paper, Erika Palmer from RURALIS (Institute for Rural and Regional Research, Norway) for proof-reading and Rodrigo Lozano from University of Gavle (Sweden) for pre-reviewing.

Conflicts of Interest: The authors declare no conflict of interest.

\section{Appendix A. Case Study 1-Cafeteria and Board Games Club, Facts and Figures}

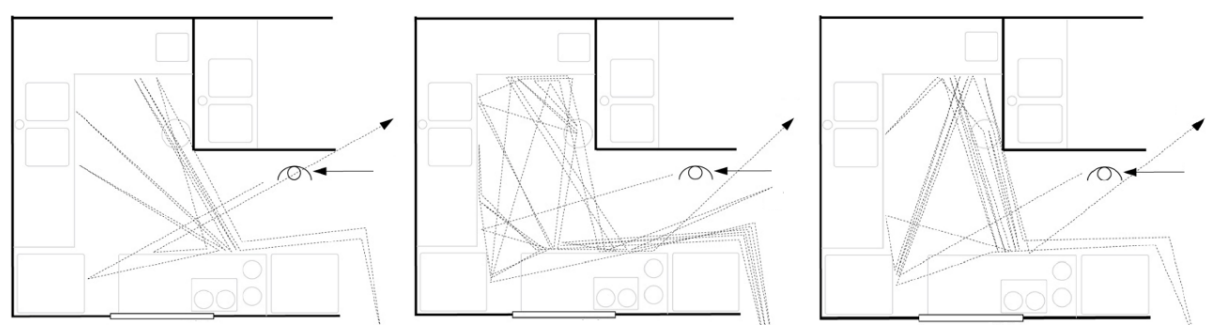

Figure A1. Spaghetti diagrams for three representative products. Adapted from [63].
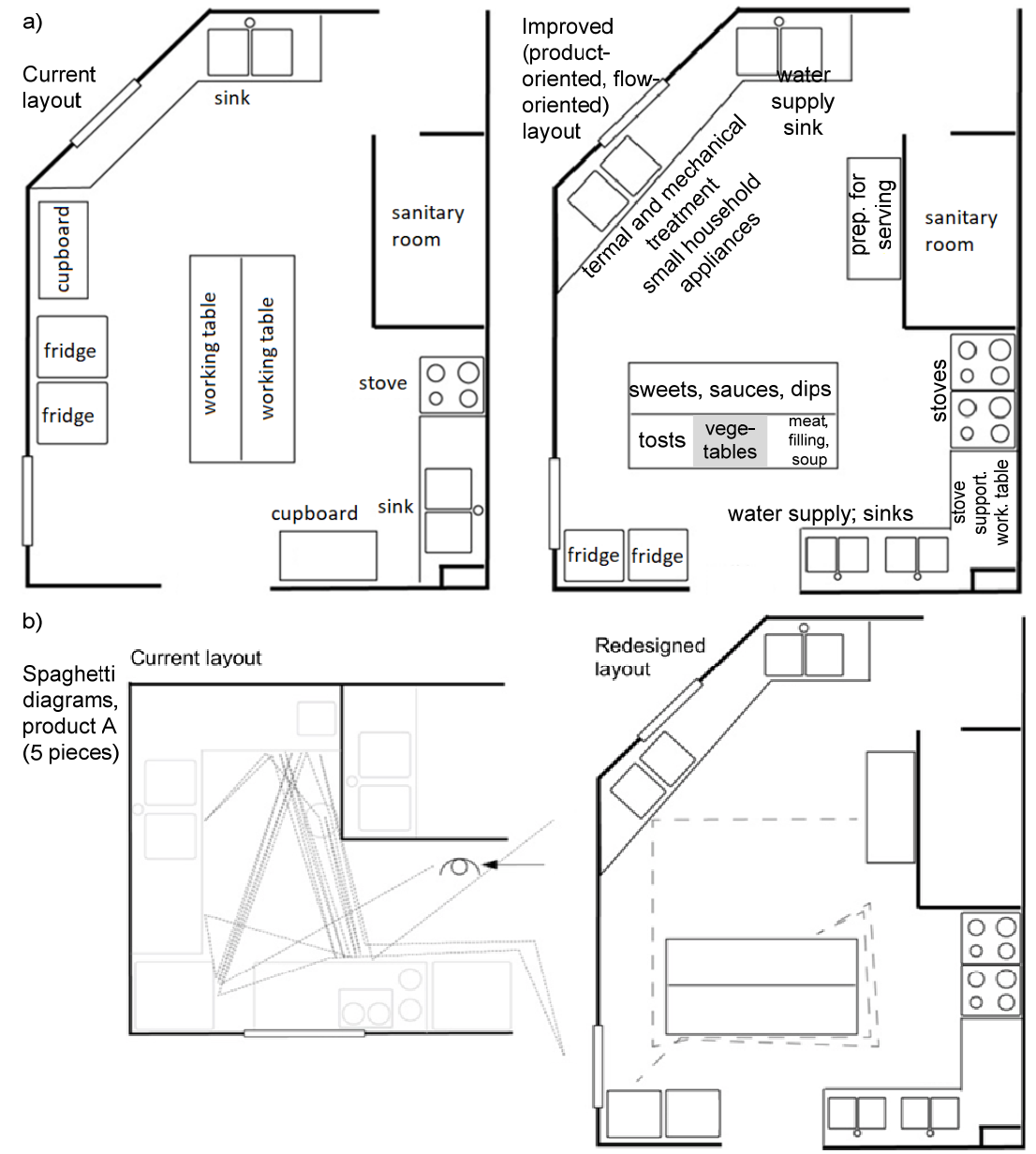

Figure A2. Impact of layout redesign on flows: (a) workstations legend; (b) flows. Adapted from [63]. 
Table A1. Parameters from job instructions for three representative products. Translated from [63].

\begin{tabular}{ccccccc}
\hline \multirow{2}{*}{ Product } & $\begin{array}{c}\text { Lead Time } \\
\text { in Minutes }\end{array}$ & $\begin{array}{c}\text { Number of } \\
\text { Operations }\end{array}$ & $\begin{array}{c}\text { Distance } \\
\text { in Meters }\end{array}$ & \multicolumn{2}{c}{ Cost in EUR } & Price \\
& Materials & Labor & in EUR \\
\hline A & 22 & 79 & 62 & 2.6 & 1.0 & 5.9 \\
B & 18 & 38 & 22 & 1.4 & 0.8 & 4.7 \\
C & 27 & 93 & 91 & 5.1 & 1.2 & 15.8 \\
\hline
\end{tabular}

Table A2. Impact of improvements on lead times and distances. Translated from [63].

\begin{tabular}{cccccccccc}
\hline \multirow{2}{*}{ Product } & \multicolumn{2}{c}{$\begin{array}{c}\text { Lead Time } \\
\text { in Minutes }\end{array}$} & \multicolumn{2}{c}{$\begin{array}{c}\text { Number of } \\
\text { Operations }\end{array}$} & \multicolumn{2}{c}{$\begin{array}{c}\text { Distance } \\
\text { in Meters }\end{array}$} & \multicolumn{2}{c}{$\begin{array}{c}\text { Cost of Labor } \\
\text { in EUR }\end{array}$} \\
\cline { 2 - 9 } & Before & After & Before & After & Before & After & Before & After \\
\hline A (5 pcs) & 22 & 8.5 & 79 & 27 & 61.5 & 13.5 & 1.00 & 0.39 \\
C (1 pc) & 27 & 11 & 93 & 55 & 90.5 & 24.5 & 1.20 & 0.44 \\
\hline
\end{tabular}

Table A3. Old and new recipe and instruction for chocolate cake. Translated from [63].

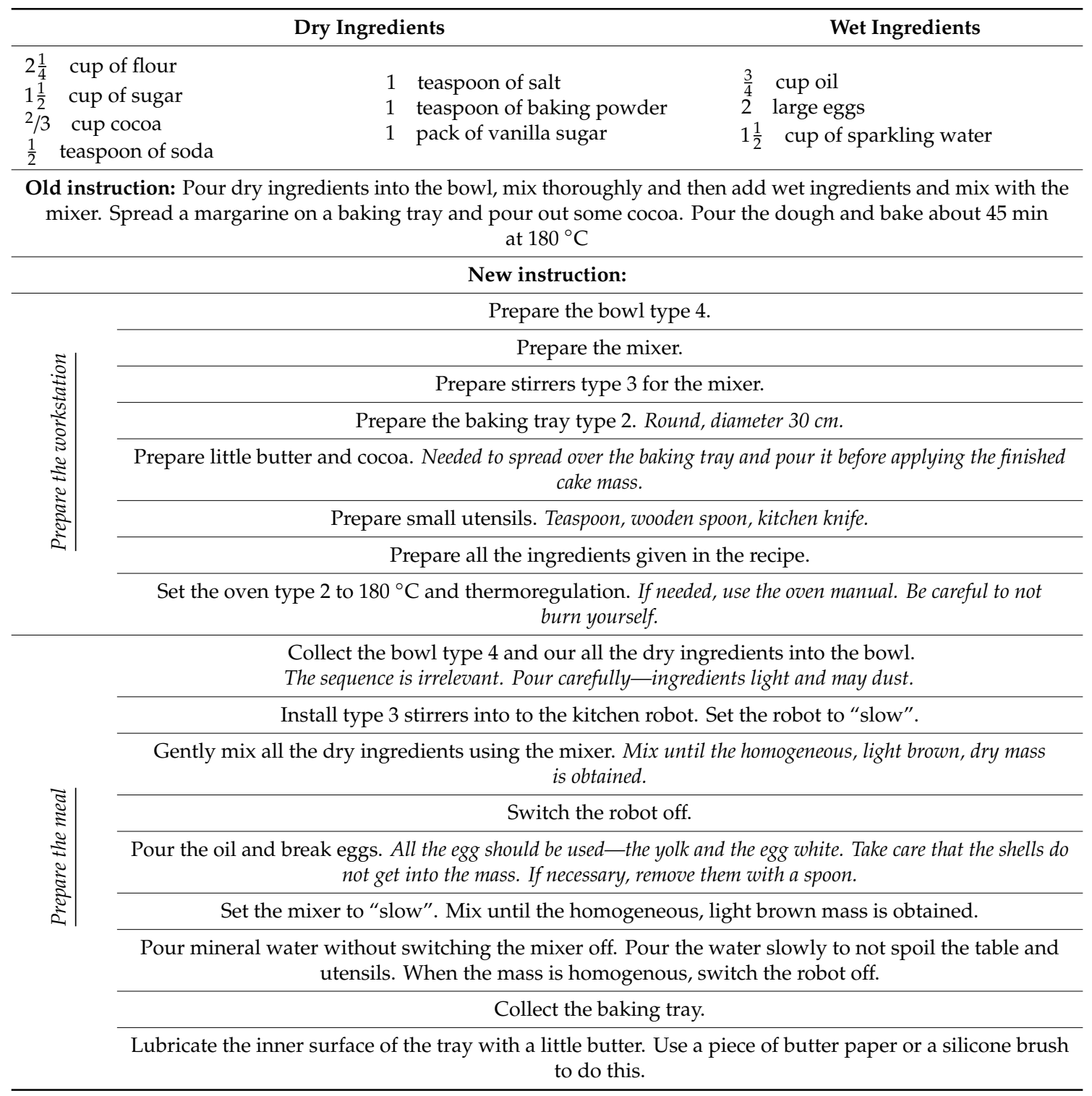


Table A3. Cont.

Pour a little cocoa ( $\frac{3}{4}$ kitchen spoon) on a baking tray and spread it evenly by shaking. The baking tray must be evenly lubricated and sprinkled with cocoa. If there is any lightening in the topping, the dough will stick there.

Pour the finished mass onto a baking tray. The mass level must be equal over the entire surface. If necessary, use a wooden spoon to distribute it evenly.

Put the baking tray in the middle level of the oven. Be careful not to burn yourself, use protective gloves. Set the timer to $45 \mathrm{~min}$.

After $20 \mathrm{~min}$, check that everything is OK. Do not open the oven door. Look through the glass and use the light inside the oven.

After $45 \mathrm{~min}$, pull out the dough and let it cool. Be careful not to burn yourself, use protective gloves.

\section{References}

1. Gladysz, B.; Buczacki, A. Wireless Technologies for Lean Manufacturing-A Literature Review. Manag. Prod. Eng. Rev. 2018, 9, 20-34. [CrossRef]

2. Frank, A. Über Verwertung der Küchenabfälle für Gewinnung von Trockenfutter und von Fett durch Ausnutzung der abgehenden Hitze der Gasanstalten, sowie anderer industrieller Betriebe. J. Für Prakt. Chem. 1915, 92, 419-424. [CrossRef]

3. Brown, L.P. Food wastes—some causes and remedies. J. Frankl. Inst. 1918, 185, 585-610. [CrossRef]

4. JAMA. The prevention of food waste. J. Am. Med. Assoc. 1920, 74, 892. [CrossRef]

5. Gruber, T.K.; Hammond, C.A. Food waste as an administrative problem. Am. J. Psychiatry 1943, 99, 886-889. [CrossRef]

6. Daniel, C.E.H. Food-Waste Control. J. High. Educ. 1945, 16, 24-28. [CrossRef]

7. Arneil, G.C.; Badham, D.R. The Losses of Edible Food Due to Plate Waste, in Army Dining Halls. Br. J. Nutr. 1949, 2, 310-313. [CrossRef]

8. Sanborn, N.H. Waste Disposal in Food Plants. Food Technol. 1947, 1, $214-221$.

9. Lau, W.; Cipani, E. Reducing student food waste in a cafeteria-style dining setting through contingency management. Child Care Q. 1983, 12, 301-310. [CrossRef]

10. Youngs, A.J.; Nobis, G.; Town, P. Food waste from hotels and restaurants in the U.K. Waste Manag. Res. 1983, 1, 295-308. [CrossRef]

11. Dreyer, H.C.; Dukovska-Popovska, I.; Yu, Q.; Hedenstierna, C.P. A ranking method for prioritising retail store food waste based on monetary and environmental impacts. J. Clean. Prod. 2019, 210, 505-517. [CrossRef]

12. Chabada, L.; Damgaard, C.M.; Dreyer, H.C.; Hvolby, H.H.; Dukovska-Popovska, I. Logistical Causes of Food Waste: A Case Study of a Norwegian Distribution Chain of Chilled Food Products. In Proceedings of the Advances in Production Management Systems. Innovative and Knowledge-Based Production Management in a Global-Local World. IFIP WG 5.7 International Conference, Ajaccio, France, 20-24 September 2014; Grabot, B., Vallespir, B., Gomes, S., Bouras, A., Kiritsis, D., Eds.; Springer: Berlin/Heidelberg, Germany, 2014; pp. 273-280.

13. Gunders, D.; Bloom, J. Wasted: How America is Losing up to 40 Percent of Its Food from Farm to Fork to Landfill; Natural Resources Defense Council: New York, NY, USA, 2017.

14. Stenmarck, Â.; Jensen, C.; Quested, T.; Moates, G.; Buksti, M.; Cseh, B.; Juul, S.; Parry, A.; Politano, A.; Redlingshofer, B. Estimates of European Food Waste Levels; IVL Swedish Environmental Research Institute: Stockholm, Sweden, 2016.

15. Benton, D. Portion size: What we know and what we need to know. Crit. Rev. Food Sci. Nutr. 2015, 55, 988-1004. [CrossRef] [PubMed]

16. Bloom, J. American Wasteland: How America Throws Away Nearly Half of Its Food; Da Capo Books: Cambridge, MA, USA, 2010.

17. Malefors, C.; Callewaert, P.; Hansson, P.-A.; Hartikainen, H.; Pietiläinen, O.; Strid, I.; Strotmann, C.; Eriksson, M. Towards a Baseline for Food-Waste Quantification in the Hospitality Sector-Quantities and Data Processing Criteria. Sustainability 2019, 11, 3541. [CrossRef] 
18. Sirieix, L.; Lála, J.; Kocmanová, K. Understanding the antecedents of consumers' attitudes towards doggy bags in restaurants: Concern about food waste, culture, norms and emotions. J. Retail. Consum. Serv. 2017, 34, 153-158. [CrossRef]

19. Stöckli, S.; Dorn, M.; Liechti, S. Normative prompts reduce consumer food waste in restaurants. Waste Manag. 2018, 77, 532-536. [CrossRef]

20. Dhir, A.; Talwar, S.; Kaur, P.; Malibari, A. Food waste in hospitality and food services: A systematic literature review and framework development approach. J. Clean. Prod. 2020, 270, 122861. [CrossRef]

21. Papargyropoulou, E.; Lozano, R.; Steinberger, J.K.; Wright, N.; Ujang, Z. The food waste hierarchy as a framework for the management of food surplus and food waste. J. Clean. Prod. 2014, 76, 106-115. [CrossRef]

22. Holweg, M. The genealogy of lean production. J. Oper. Manag. 2007, 25, 420-437. [CrossRef]

23. Ohno, T. Toyota Production System: Beyond Large-Scale Production; CRC Press: Portland, OR, USA, 1988; ISBN 978-0-915299-14-0.

24. Blum, D. Ways to Reduce Restaurant Industry Food Waste Costs. Int. J. Appl. 2020, 19, 1-12. [CrossRef]

25. Bicheno, J.; Holweg, M. The Lean Toolbox: A Handbook for Lean Transformation; PICSIE Books: Buckingham, UK, 2016.

26. Womack, J.P.; Jones, D.T. Lean Thinking-Banish Waste and Create Wealth in your Corporation. J. Oper. Res. Soc. 1997, 48, 1148. [CrossRef]

27. Papargyropoulou, E.; Wright, N.; Lozano, R.; Steinberger, J.; Padfield, R.; Ujang, Z. Conceptual framework for the study of food waste generation and prevention in the hospitality sector. Waste Manag. 2016, 49, 326-336. [CrossRef] [PubMed]

28. Papargyropoulou, E.; Steinberger, J.K.; Wright, N.; Lozano, R.; Padfield, R.; Ujang, Z. Patterns and Causes of Food Waste in the Hospitality and Food Service Sector: Food Waste Prevention Insights from Malaysia. Sustainability 2019, 11, 6016. [CrossRef]

29. Clowes, A.; Hanson, C.; Swanell, R. The Business Case for Reducing Food Loss and Waste: Restaurants. 2019. Champions 12.3. Available online: www.champions123.org (accessed on 4 December 2020).

30. Pirani, S.I.; Arafat, H.A. Reduction of food waste generation in the hospitality industry. J. Clean. Prod. 2016, 132, 129-145. [CrossRef]

31. Vizzoto, F.; Tessitore, S.; Iraldo, F.; Testa, F. Passively concerned: Horeca managers' recognition of the importance of food waste hardly leads to the adoption of more strategies to reduce it. Waste Manag. 2020, 107, 266-275. [CrossRef]

32. Lasek, A.; Cercone, N.; Saunders, J. Restaurant Sales and Customer Demand Forecasting: Literature Survey and Categorization of Methods. In Proceedings of the First EAI International Summit, Smart City $360^{\circ}$, Bratislava, Slovakia and Toronto, ON, Canada, 13-16 October 2015; Leon-Garcia, A., Lenort, R., Holman, D., Staš, D., Krutilova, V., Wicher, P., Cagáňová, D., Špirková, D., Golej, J., Nguyen, K., Eds.; Springer International Publishing: Cham, Switzerland, 2016; pp. 479-491.

33. Heikkilä, L.; Reinikainen, A.; Katajajuuri, J.-M.; Silvennoinen, K.; Hartikainen, H. Elements affecting food waste in the food service sector. Waste Manag. 2016, 56, 446-453. [CrossRef]

34. Tsai, W.-T. Turning Food Waste into Value-Added Resources: Current Status and Regulatory Promotion in Taiwan. Resources 2020, 9, 53. [CrossRef]

35. Laakso, S. Creating New Food Practices: A Case Study on Leftover Lunch Service. Food Cult. Soc. 2017, 20, 631-650. [CrossRef]

36. Luciano, A.; Tretola, M.; Ottoboni, M.; Baldi, A.; Cattaneo, D.; Pinotti, L. Potentials and Challenges of Former Food Products (Food Leftover) as Alternative Feed Ingredients. Animals 2020, 10, 125. [CrossRef]

37. Castrica, M.; Tedesco, D.E.A.; Panseri, S.; Ferrazzi, G.; Ventura, V.; Frisio, D.G.; Balzaretti, C.M. Pet Food as the Most Concrete Strategy for Using Food Waste as Feedstuff within the European Context: A Feasibility Study. Sustainability 2018, 10, 2035. [CrossRef]

38. Jiménez-Antillón, J.; Calleja-Amador, C.; Romero-Esquivel, L.G. Food Waste Recovery with Takakura Portable Compost Boxes in Offices and Working Places. Resources 2018, 7, 84. [CrossRef]

39. Franchetti, M. Development of a Novel Food Waste Collection Kiosk and Waste-to-Energy Business Model. Resources 2016, 5, 26. [CrossRef]

40. Sakaguchi, L.; Pak, N.; Potts, M.D. Tackling the issue of food waste in restaurants: Options for measurement method, reduction and behavioral change. J. Clean. Prod. 2018, 180, 430-436. [CrossRef] 
41. Bergström, P.; Malefors, C.; Strid, I.; Hanssen, O.J.; Eriksson, M. Sustainability Assessment of Food Redistribution Initiatives in Sweden. Resources 2020, 9, 27. [CrossRef]

42. Suárez-Barraza, M.F.; Smith, T.; Dahlgaard-Park, S.M. Lean Service: A literature analysis and classification. Total Qual. Manag. Bus. Excell. 2012, 23, 359-380. [CrossRef]

43. Abdelhadi, A. Using lean manufacturing as service quality benchmark evaluation measure. Int. J. Lean Six Sigma 2016, 7, 25-34. [CrossRef]

44. Abdi, F.; Shavarini, S.K.; Seyed Hoseini, S.M. Glean lean: How to use lean approach in service industries? J. Serv. Res. 2006, 6, 191-206.

45. Alva, I.; Rojas, J.; Raymundo, C. Improving Processes Through the Use of the 5S Methodology and Menu Engineering to Reduce Production Costs of a MSE in the Hospitality Sector in the Department of Ancash. In Proceedings of the Human Interaction and Emerging Technologies, Nice, France, 22-24 August 2019; Ahram, T., Taiar, R., Colson, S., Choplin, A., Eds.; Springer International Publishing: Cham, Switzerland, 2020; pp. 818-824.

46. Bowen, D.E.; Youngdahl, W.E. “Lean” service: In defense of a production-line approach. Int. J. Serv. Ind. Manag. 1998, 9, 207-225. [CrossRef]

47. Indrawati, S.M.; Azzam, A.; Adrianto, E.; Miranda, S.; Prabaswari, A.D. Lean Concept Development in Fast Food Industry Using Integration of Six Sigma and TRIZ Method. In Proceedings of the IOP Conference Series: Materials Science and Engineering, 3rd International Conference on Engineering Technology for Sustainable Development (ICET4SD), Yogakarta, Indonesia, 23-24 October 2019; IOP Publishing: Bristol, UK, 2020; Volume 722, pp. 012044:1-012044:7.

48. Keyser, R.S.; Clay, K.; Marella, V.K. Lean Restaurants: Improving the Dining Experience. J. High. Educ. Theory Pract. 2017, 17, 67-79.

49. LeGrand, C.; Pawar, N.; Digraskar, S.; Mahajan, S.; Mishra, S.; Polson, S. Lean restaurant. In Lean Systems: Applications and Case Studies in Manufacturing, Service, and Healthcare; Cudney, E.A., Furterer, S., Dietrich, D., Eds.; CRC Press: Boca Raton, FL, USA, 2013; ISBN 978-1-4665-5681-2.

50. Pan, W.-T.; Leu, Y.; Zhu, W.; Lin, W.-Y. A Data Mining Approach to the Analysis of a Catering Lean Service Project. Intell. Autom. Soft Comput. 2017, 23, 243-250. [CrossRef]

51. Rahimnia, F.; Moghadasian, M.; Castka, P. Benchmarking leagility in mass services: The case of a fast food restaurant chains in Iran. Benchmarking Int. J. 2009, 16, 799-816. [CrossRef]

52. Tucki, K.; Baczyk, A.; Prystasz, M. Options for Implementing Lean Management Elements (Case Study of a Restaurant at the Warsaw Chopin Airport). In Proceedings of the International Scientific Days 2018. Towards Productive, Sustainable and Resilient Global Agriculture and Food Systems, Nitra, Slovak Republic, 16-17 May 2018; Wolters Kluwer: Prague, Czech Republic, 2018; pp. 510-518.

53. Application of Lean Management to the Tourism, Hotel and/or Restaurant Sector. Master's Thesis, Universitat Politecnica de Catalunya, Barcelona, Spain, 2018.

54. Dyrina, E.; Gavrikova, N. Experience in applying lean production concepts in the service sector. SHS Web Conf. 2016, 28, 01030. [CrossRef]

55. Szymanska-Bralkowska, M.; Malinowska, E. The use of selected green lean instruments to improve catering services. Sci. Pap. Silesian Univ. Technol. Organ. Manag. Ser. 2019, 136, 601-608. [CrossRef]

56. Eisenhardt, K.M. Building Theories from Case Study Research. Acad. Manage. Rev. 1989, 14, 532-550. [CrossRef]

57. Shah, S.R.; Naghi Ganji, E. Lean production and supply chain innovation in baked foods supplier to improve performance. Br. Food J. 2017, 119, 2421-2447. [CrossRef]

58. Francis, M.; Simons, D.; Bourlakis, M. Value chain analysis in the UK beef foodservice sector. Supply Chain Manag. Int. J. 2008, 13, 83-91. [CrossRef]

59. Ma, J.; Ghiselli, R. Measuring, monitoring, and managing the green practices in mid-sized restaurants in China. J. Foodserv. Bus. Res. 2016, 19, 64-76. [CrossRef]

60. Morales-Contreras, M.F.; Suárez-Barraza, M.F.; Leporati, M. Identifying Muda in a fast food service process in Spain. Int. J. Qual. Serv. Sci. 2020, 12, 201-226. [CrossRef]

61. Muller, C. The Restaurant as Hybrid: Lean Manufacturer and Service Provider. Boston Hosp. Rev. 2012, Fall, 39-47.

62. Orynycz, O.; Tucki, K.; Prystasz, M. Implementation of Lean Management as a Tool for Decrease of Energy Consumption and $\mathrm{CO}_{2}$ Emissions in the Fast Food Restaurant. Energies 2020, 13, 1184. [CrossRef] 
63. Nowicki, J. Reorganization of the Cafeteria Considering the Change of Its Internal Culture; Postgraduate; Warsaw University of Technology-Kaizen Academy: Warsaw, Poland, 2018.

64. Dinero, D. Training Within Industry; Productivity Press: Portlan, OR, USA, 2005.

65. Kniberg, H. Lean from the Trenches: Managing Large-Scale Projects with Kanban; Pragmatic Bookshelf: Stockholm, Sweden, 2011.

66. Kim, W.C.; Mauborgne, R.A. Blue Ocean Leadership, 2nd ed.; Harvard Business School Publishing: Boston, MA, USA, 2017.

67. Dalton, J. Great Big Agile: An OS for Agile Leaders; Apress: Berkeley, NY, USA, 2019.

68. Nadler, D.A.; Lawler III, E.E. Motivation: A diagnostic approach. Read. Manag. Psychol. 1989, 3, 3-19.

69. Szewczyk, P. A Project of Modernization of Central Kitchen in a Production and Service Company Based on Selected Kaizen Tools; Postgraduate; Warsaw University of Technology_Kaizen Academy: Warsaw, Poland, 2019.

70. Karbowniczak, B. Analysis of the Possibility of Using Selected Kaizen Tools to Improve the Efficiency of a Gastronomic Facility; Postgraduate; Warsaw University of Technology_Kaizen Academy: Warsaw, Poland, 2014.

Publisher's Note: MDPI stays neutral with regard to jurisdictional claims in published maps and institutional affiliations.

(C) 2020 by the authors. Licensee MDPI, Basel, Switzerland. This article is an open access article distributed under the terms and conditions of the Creative Commons Attribution (CC BY) license (http://creativecommons.org/licenses/by/4.0/). 